\title{
Uji Aktivitas Antioksidan Ekstrak Daun Karet Kebo (Ficus elastica) dengan Metode Peredaman Radikal Bebas DPPH (1,1-Diphenyl-2- Picrylhydrazil)
}

\section{(Antioxidant Assay of Ficus elastica Leaf Extract with DPPH (1,1-diphenyl-2- phycrilhydrazyl) Free Radical Scavenging Method)}

\author{
Selpida Handayani ${ }^{1}$, Ida Kurniawati ${ }^{1}$, Faradiba Abdul Rasyid ${ }^{1 *}$ \\ 1*Jurusan Farmasi, Fakultas Farmasi, Universitas Muslim Indonesia, Makassar, Indonesia. \\ E-mail: faradiba.faradiba@umi.ac.id
}

Article Info:

Received: 18 Februari 2020

in revised form: 10 Maret 2020

Accepted: 14 Maret 2020

Available Online: 15 Maret 2020

Keywords:

Antioxidants

Ficus elastica Leaf

1,1-diphenyl-2-phycrilhydrazyl

Corresponding Author:

Faradiba Abdul Rasyid

Jurusan Farmasi

Fakultas Farmasi

Universitas Muslim Indonesia

Makassar

Indonesia

90231

email: faradiba.faradiba@umi.ac.id

\begin{abstract}
Ficus elastica leaf is one of the Ficus species assumed to be rich in polyphenols so that it can act as an antioxidant. The research aimed to determine the antioxidant activity and $\mathrm{IC}_{50}$ value of methanol and water extracts of rubber leaf. In this research, the extraction was conducted by maceration using methanol and obtained the yield value of 7,03\%, while the infundation using water obtained the yield value of $2,82 \%$. The antioxidant activity test was conducted by DPPH (1,1-diphenyl-2-phycrilhydrazyl) free radical scavenging using a quercetin as comparator. The qualitative tests were conducted by TLC method using dicloromethane:methanol eluent with a ratio of 99:1 for methanol extracts, and a ratio of 95:5 for water extracts, where all extracts of both methanol and water positively contain antioxidants characterized by the formation of yellow spots with a purple background on TLC plates. The results of the quantitative test showed that the methanol extract had medium antioxidant activity with an $\mathrm{IC}_{50}$ value of $78,39 \mu \mathrm{g} / \mathrm{mL}$, and water extract had an inactive antioxidant activity with an $\mathrm{IC}_{50}$ value of $319,11 \mu \mathrm{g} / \mathrm{mL}$. Meanwhile, quercetin was classified as a very strong antioxidant with an $\mathrm{IC}_{50}$ value of $7,62 \mu \mathrm{g} / \mathrm{mL}$.
\end{abstract}

How to cite (APA $6^{\text {th }}$ Style):

Handayani, S., Kurniawati, I., Rasyid, F. A. (2020). Uji Aktivitas Antioksidan Ekstrak Daun Karet Kebo (Ficus elastica) dengan Metode Peredaman Radikal Bebas DPPH (1,1-Diphenyl-2-Picrylhydrazil). Jurnal Farmasi Galenika :Galenika Journal of Pharmacy (e-Journal), 6(1), 141-150. doi:10.22487/j24428744.2020.v6.i1.15022 


\section{ABSTRAK}

Daun karet kebo (Ficus elastica) merupakan salah satu spesies Ficus yang diduga kaya akan senyawa polifenol sehingga dapat beraktivitas sebagai antioksidan. Tujuan penelitian ini adalah mengetahui aktivitas antioksidan dan nilai $\mathrm{IC}_{50}$ dari ekstrak metanol dan air daun karet kebo(Ficus elastica). Pada penelitian ini, ekstraksi dilakukan dengan menggunakan metode maserasi dengan pelarut metanol dan diperoleh $\%$ rendamen sebesar $7,03 \%$, sementara metode infundasi dengan pelarut air diperoleh rendamen sebesar 2,82\%. Uji aktivitas antioksidan dilakukan dengan metode peredaman radikal bebas 1,1-Diphenyl-2-Phycrilhydrazyl dengan menggunakan pembanding kuersetin. Uji kualitatif dilakukan dengan menggunakan metode KLT dengan eluen diklorometan:metanol dengan perbandingan 99:1 untuk ekstrak metanol, dan perbandingan 95:5 untuk ekstrak air, dimana semua ekstrak baik metanol maupun air positif mengandung antioksidan yang ditandai dengan terbentuknya bercak kuning berlatar belakang ungu pada lempeng KLT. Dari hasil uji kuantitatif, diperoleh nilai $\mathrm{IC}_{50}$ ekstrak metanol 78,39 $\mu \mathrm{g} / \mathrm{mL}$ dengan aktivitas antioksidan sedang, dan nilai $\mathrm{IC}_{50}$ ekstrak air $319,11 \mu \mathrm{g} / \mathrm{mL}$ yang menunjukkan tidak aktif sebagai antioksidan. Sedangkan kuersetin memiliki nilai $\mathrm{IC}_{50} 7,62 \mu \mathrm{g} / \mathrm{mL}$ yang tergolong antioksidan sangat kuat.

Kata Kunci : Antioksidan, Daun karet kebo, Ficus elastica, 1,1-diphenyl-2-phycrilhydrazyl.

\section{PENDAHULUAN}

Radikal bebas adalah suatu molekul yang memiliki satu atau lebih elektron bebas atau tidak berpasangan, sehingga radikal bebas bersifat tidak stabil. Karena sifatnya yang tidak stabil, radikal bebas bersifat sangat reaktif dan dapat mengikat molekul-molekul atau senyawa disekitarnya untuk pemperoleh pasangan elektron dan mencapai kestabilan. Radikal bebas dapat terbentuk dalam tubuh serta berlangsung secara terus menerus sehingga dapat menyebabkan timbulnya berbagai penyakit. Antioksidan dapat menetralkan radikal bebas melalui donor elektron sehingga radikal bebas lebih stabil dan tidak reaktif (Huselan et al., 2015). Senyawa-senyawa yang bersifat antioksidan dapat diperoleh dari berbagai sumber, salah satunya adalah antioksidan alami yang dapat diperoleh dari tanaman.

Ficus merupakan spesies yang kaya akan senyawa polifenol, seperti flavonoid yang bersifat antioksidan kuat yang dapat membantu dalam pencegahan dan pengobatan berbagai penyakit yang disebabkan karena stress oksidatif (Sirisha et al., 2010).
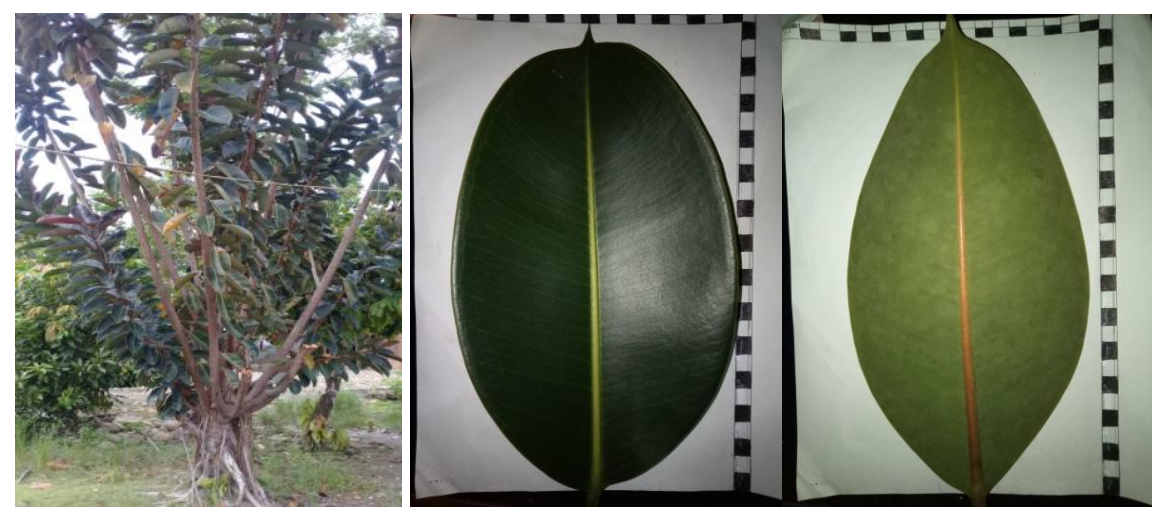

Gambar 1. Pohon dan Daun Karet kebo (Ficus elastica)

Karet kebo (Ficus elastica) merupakan tanaman yang berasal dari India. Tanaman ini biasa dipelihara sebagai tanaman hias maupun tumbuh sebagai tanaman liar, dan dapat ditemukan sampai ketinggian $500 \mathrm{~m}$ dpl. Pohon Karet kebo (Ficus elastica) seperti pada gambar 1 mempunyai tinggi 8 sampai $40 \mathrm{~m}$, pada batangnya terdapat akar udara yang menggantung, dan getahnya berwarna putih. Daun tunggal dan berbentuk memanjang. Bertangkai panjang dan daunnya tersebar dengan pucuk daun di ujung tangkai tergulung dilapisi seludang tipis berwarna merah (Dalimartha, 2008). Menurut 
beberapa literatur, ekstrak daun Ficus elastica dapat dimanfaatkan sebagai pengobatan disentri, antiemetik, hipotensi, alergi dan infeksi kulit, anemia neurodegeneratif, penyakit hati dan sebagai agen diuretik (Saeed et al., 2017).

Berdasarkan penelitian Iqbal (2018), minyak esensial akar Karet kebo (Ficus elastica) menunjukkan peningkatan persen aktivitas antioksidan seiring dengan penambahan konsentrasi. Untuk itu dilakukan uji aktivitas antioksidan pada ekstrak metanol dan ekstrak air daun karet kebo (Ficus elastica), dimana metode yang digunakan adalah analisis DPPH yang diukur dengan spektrofotometri UV-Vis. Pembanding yang digunakan adalah Kuersetin.

\section{METODE PENELITIAN}

\section{Alat dan Bahan}

Alat yang digunakan adalah alat maserasi dan infundasi, alat-alat gelas laboratorium (Pyrex), camber, lampu UV $256 \mathrm{~nm}$ dan $366 \mathrm{~nm}$, mikro pipet (Dragon Lab), rotavapor (IKA® RV O5BASIC), spektrofotometer UV-Vis (Thermo Scientific) dan timbangan analitik (Carat series). Bahan-bahan yang digunakan adalah aquadest, Diklorometana, DPPH (1,1-Diphenyl-2-Picrylhidrazil), kuersetin, lempeng silika gel F254, metanol, pereaksi skrining fitokimia.

\section{Metode}

\section{Ekstraksi}

\section{Maserasi}

Simplisia daun karet kebo (Ficus elastica) yang telah diserbukkan, ditimbang sebanyak 100 gram lalu di masukkan dalam bejana maserasi dan ditambahkan dengan $800 \mathrm{~mL}$ metanol. Ekstraksi dilakukan selama 1 x 24 jam kemudian disaring. Residu kemudian remaserasi sebanyak 2 kali dengan pelarut metanol yang baru. Filtrat selanjutnya diuapkan dengan Rotary Vacum Evaporator sehingga diperoleh ekstrak kental.

\section{Infundasi}

Infusa daun karet kebo (Ficus elastica) dibuat dengan cara memanaskan 50 gram serbuk simplisia kedalam air sebanyak $500 \mathrm{~mL}$ dan dipanaskan dalam waktu 15 menit menggunakan penangas air pada suhu $90^{\circ} \mathrm{C}$ sambil sekali-kali diaduk. Setelah itu, infusa disaring selagi panas dengan menggunakan kain flannel. Selanjutnya dihilangkan kandungan airnya dengan Freeze dry.

\section{Skrining fitokimia}

Prosedur skrining fitokimia menurut Harborne (1987) adalah sebagai berikut:

\section{Uji Alkaloid}

Larutan uji dimasukkan kedalam tabung reaksi kemudian ditambahkan dengan $\mathrm{HCl} 2 \mathrm{~N}$. Tabung pertama ditambahkan pereaksi mayer dan tabung kedua pereaksi dragendorf. Positif jika terbentuk endapan putih pada tabung pertama dan endapan jingga di tabung kedua.

\section{Uji Flavonoid}

Larutan eksrak metanol dan air yang telah dilarutkan dimasukkan ke 2 tabung reaksi, kemudian tabung pertama ditetesi dengan $\mathrm{NaOH} 10 \%$. Apabila terjadi perubahan warna kuning, hijau, coklat atau merah artinya sampel positif mengandung flavonoid. Selanjutnya tabung kedua di tambahkan serbuk $\mathrm{Mg}+\mathrm{HCl}$ pekat, mengandung flavonoid jika terbentuk buih dan terjadi perubahan warna kuning, jingga atau merah. 


\section{Uji Tanin}

Larutan uji dimasukkan ke dalam tabung reaksi, kemudian ditambahkan beberapa tetes larutan $\mathrm{FeCl}_{3}$. Positif Tanin jika terbentuk warna hijau/biru kehitaman.

\section{Uji Saponin}

Sebanyak $1 \mathrm{~mL}$ larutan uji dimasukkan dalam tabung reaksi dan ditambahkan $10 \mathrm{~mL}$ aquades panas. Campuran dikocok sampai muncul buih dan didiamkan selama 1 menit. Selanjutnya ditambahkan dengan 2 tetes $\mathrm{HCl} 2 \mathrm{~N}$ dan dikocok lagi sampai terbentuk buih. Adanya senyawa saponin ditandai dengan terbentuknya buih yang stabil selama 10 menit dengan tinggi $3 \mathrm{~cm}$.

\section{Uji Triterpenoid/Steroid}

Larutan ekstak metanol dan ekstrak air dimasukkan kedalam tabung, kemudian ditambahkan pereaksi $\mathrm{CH}_{3} \mathrm{COOH}$ a.h dan $\mathrm{H}_{2} \mathrm{SO}_{4}$ melalui dinding tabung. Apabila terbentuk cincin kecoklatan/violet, menunjukkan sampel positif mengandung triterpenoid, dan terbentuknya cincin biru kehijauan menunjukkan positif adanya steroid.

\section{Uji Kualitatif Aktivitas Antioksidan}

Metode pengujian aktivitas antioksidan mengacu pada penelitian Wahdaningsih, (2011) dimana pengujian dilakukan dengan cara melarutkan ekstrak metanol dan air daun karet kebo (Ficus elastica) dengan pelarut metanol. Kemudian ditotolkan pada lempeng silika gel $\mathrm{F}_{254}$ dan dielusi dengan eluen Diklorometana:Metanol perbandingan 95:5 untuk ekstrak metanol dan 99:1 untuk ekstrak air. Setelah dielusi lempeng diangin-anginkan lalu diamati di UV $254 \mathrm{~nm}$ dan $366 \mathrm{~nm}$, kemudian lempeng KLT disemprot dengan larutan DPPH 0,2\%. Sampel positif memiliki aktivitas sebagai antioksidan apabila terbentuk bercak kuning pada lempeng.

\section{Uji Kuantitatif Aktivitas Antioksidan}

\section{Pembuatan Larutan stok DPPH}

Serbuk DPPH ditimbang sebanyak $3 \mathrm{mg}$. Dilarutkan pada metanol p.a $100 \mathrm{~mL}$ (30 ppm) kemudian dihomogenkan.

\section{Penentuan Panjang Gelombang Maksimal DPPH}

Larutan stok DPPH konsentrasi 30 ppm dipipet sebanyak 4 mL. Kemudian pengukuran panjang gelombang maksimal dilakukan dengan mengukur absorbansi larutan DPPH pada spektrofotometer dengan panjang gelombang $500-525 \mathrm{~nm}$

\section{Pembuatan Stok Larutan Pembanding}

Larutan stok pembanding dibuat pada konsentrasi 100 ppm. Serbuk kuersetin ditimbang $1 \mathrm{mg}$ dilarutkan dengan metanol kemudian dihomogenkan dalam labu ukur $10 \mathrm{~mL}$ dan cukupkan volumenya. Dibuat seri konsentrasi 2 ppm, 4 ppm, 6 ppm, 8 ppm, dan 10 ppm.

\section{Pengukuran Aktivitas Antioksidan Ekstrak Daun Karet Kebo (Ficus elastica)}

Ekstrak metanol dan air masing-masing ditimbang sebanyak $10 \mathrm{mg}$ dan dimasukkan larutkan dengan metanol p.a kedalam labu ukur $10 \mathrm{~mL}$ kemudian dicukupkan volumenya dan dihomogenkan (1000 ppm). Kemudian lakukan pengenceran sehingga diperoleh seri konsentrasi 20 ppm, 40 ppm, 60 ppm, $80 \mathrm{ppm}$, dan $100 \mathrm{ppm}$. Selanjutnya uji kuantitatif dilakukan dengan memipet masing-masing konsentrasi larutan sebanyak $0,5 \mathrm{~mL}$ dengan pipet mikro dan masukan ke dalam vial, kemudian 
tambahkan 3,5 mL larutan DPPH. Campuran dihomogenkan dan diinkubasi selama 30 menit, serapan diukur dengan spektrofotometer UV-Vis pada panjang gelombang maksimal $516 \mathrm{~nm}$. Aktivitas antioksidan sampel ditentukan oleh besarnya hambatan serapan radikal DPPH melalui perhitungan \% inhibisi menggunakan rumus:

$$
\% \text { Inhibisi }=\frac{\left[A_{o}-\left(A_{s}-A_{e}\right)\right]}{A_{\circ}} \times 100 \%
$$

Keterangan :

$A_{o}=$ Absorbansi DPPH pada panjang gelombang maksimum.

$A_{s}=$ Absorbansi larutan sampel uji ditambah larutan DPPH

$A_{e}=$ Absorbansi larutan sampel uji tanpa DPPH

Selanjutnya hasil pengukuran dimasukkan ke dalam persamaan regresi dengan konsentrasi ekstrak sebagai sumbu $\mathrm{X}$ (absis) dan nilai \% inhibisi sebagai sumbu Y, dimana untuk menghitung Nilai $\mathrm{IC}_{50}$ nilai Y (\% inhibisi) sebesar 50\%.

Dari persamaan persamaan garis, dapat dihitung nilai $\mathrm{IC}_{50}$ dengan rumus:

$$
\mathrm{IC}_{50}=\frac{50-a}{b}
$$

$$
\begin{aligned}
\text { Dimana: } & \mathrm{y}=\% \text { inhibisi }(50) \\
& \mathrm{a}=\text { Intercept (Perpotongan garis di sumbu } \mathrm{y}) \\
\mathrm{b} & =\text { Slope (kemiringan) } \\
\mathrm{x} & =\text { Konsentrasi }
\end{aligned}
$$

\section{HASIL DAN PEMBAHASAN}

Pada tahap ekstraksi, metode yang digunakan terdiri dari metode maserasi dan infundasi. Pada metode maserasi, pelarut yang digunakan yakni pelarut metanol. Tujuan digunakannya pelarut metanol karena harganya yang relatif terjangkau, metanol memiliki tetapan dielektrik yang lebih rendah daripada air. Menurut Agustina (2017), semakin tinggi tetapan dielektrik maka tingkat kepolaran pelarut semakin besar juga sehingga dapat melarutkan semua zat, baik yang bersifat polar maupun semipolar. Pemilihan metode maserasi dalam ektraksi karena tidak memerlukan peralatan khusus dan cocok untuk mengekstraksi sampel yang bersifat lunak seperti daun.

Selain di gunakan metode maserasi, ekstraksi juga dilakukan dengan metode infundasi. Metode ini cocok untuk sampel daun dan tehnik perebusan seperti ekstraksi infundasi banyak dilakukan oleh masyarakat untuk mengolah tanaman obat secara tradisional (Saifuddin, 2014). Selain itu, pelarut air bersifat tidak toksik, serta lebih polar dibandingkan metanol. Jumlah ekstrak dan persen rendamen dari kedua metode ekstraksi tersebut dapat dilihat pada tabel berikut:

Tabel 1. Jumlah ekstrak dan persen rendamen ekstrak metanol dan ekstrak air daun karet kebo (Ficus elastica).

\begin{tabular}{lcccc}
\hline \multicolumn{1}{c}{ Sampel } & $\begin{array}{c}\text { Jenis } \\
\text { Pelarut }\end{array}$ & $\begin{array}{c}\text { Berat } \\
\text { Sampel (g) }\end{array}$ & $\begin{array}{c}\text { Berat } \\
\text { ekstrak (g) }\end{array}$ & $\begin{array}{c}\text { Rendamen } \\
\text { ekstrak (\%) }\end{array}$ \\
\hline $\begin{array}{l}\text { Daun Karet kebo } \\
\text { (Ficus elastica) }\end{array}$ & Metanol & 100 & 7,03145 & 7,03 \\
& Air & 50 & 1,4108 & 2,82 \\
\hline
\end{tabular}


Dari hasil ekstraksi maserasi, maserat diuapkan dengan Rotary vacum evaporator dan infusa di keringkan dengan freeze dryer. Jumlah ekstrak metanol yang diperoleh lebih banyak dibandingkan ekstrak air jika dilihat dari persen rendamen. Pada ekstrak metanol persen rendamen yang diperoleh $7,03 \%$ sementara ekstrak air 2,82 \%. Hal ini menunjukan bahwa pelarut metanol lebih banyak menarik senyawa kimia dibandingkan pelarut air. Pada struktur kimia metanol memiliki dua sisi yakni gugus hidroksil $(-\mathrm{OH})$ yang bersifat polar polar dan gugus metil $\left(\mathrm{CH}_{3}\right)$ yang bersifat non polar, sehingga metanol dapat melarutkan beberapa metabolit yang non polar (Aziz et al., 2014).

Setelah di peroleh masing-masing ekstrak, di lakukan uji skrining untuk mengetahui komponen senyawa kimia yang ikut tertarik pada saat dilakukan ekstraksi. Pengujian dilakukan dengan uji tabung

Tabel 2. Hasil uji skrining fitokimia ekstrak daun karet kebo (Ficus elastica).

\begin{tabular}{|c|c|c|c|c|}
\hline \multirow{2}{*}{$\begin{array}{l}\text { Golongan } \\
\text { Senyawa }\end{array}$} & \multirow[t]{2}{*}{ Pereaksi } & \multirow[t]{2}{*}{ Reaksi Positif } & \multicolumn{2}{|c|}{$\begin{array}{c}\text { Hasil pengamatan } \\
\text { ekstrak }\end{array}$} \\
\hline & & & Metanol & Air \\
\hline \multirow{2}{*}{ Alkaloid } & Mayer & endapan Putih & - & - \\
\hline & Dragendorf & endapan Jingga & - & - \\
\hline Fenol/Tanin & $\mathrm{FeCl}_{3}$ & Hijau/biru kehitaman & + & + \\
\hline \multirow{2}{*}{ Flavonoid } & $\mathrm{NaOH}$ & Warna jingga kemerahan & + & + \\
\hline & Serbuk Mg + HCl Pekat & Warna kuning, jingga/merah & + & + \\
\hline Saponin & $\begin{array}{l}\text { Aquadest panas } \\
+\mathrm{HCl} 2 \mathrm{~N}\end{array}$ & $\begin{array}{c}\text { Buih (pengocokan) } \\
\text { Buih yang stabil }\end{array}$ & + & + \\
\hline $\begin{array}{l}\text { Triterpenoid atau } \\
\text { steroid }\end{array}$ & $\begin{array}{c}\mathrm{CH}_{3} \mathrm{COOH} \text { a.h }+ \\
\mathrm{H}_{2} \mathrm{SO}_{4}\end{array}$ & $\begin{array}{c}\text { Cicin kecoklatan /violet } \\
\text { (triterpenoid) atau hijau kebiruan } \\
\text { (steroid) }\end{array}$ & - & - \\
\hline
\end{tabular}

Pada pengujian skrining, alkaloid diidentifikasi dengan penambahan $\mathrm{HCl}$ terlebih dahulu. Alkaloid merupakan metabolit sekunder yang bersifat basa dalam larut dalam bentuk garamnya, sehingga perlu di tambahkan asam terlebih dahulu. Selanjutnya digunakan pereaksi mayer dan dragendorf, dimana pada pereaksi mayer reaksi positif akan ditunjukan dengan terbentuknya endapan berwarna putih

sedangkan pada pereaksi dragendorf akan terbentuk endapan jingga. Alkaloid memiliki atom nitrogen yang memiliki pasangan elektron bebas, sehingga dapat membentuk ikatan kovalen koordinasi dengan ion $\mathrm{K}^{+}$dari pereaksi kalium tetraiodomerkurat(II) (Mayer) dan kalium tetraiodobismutat (Dragendorf) membentuk kalium-alkaloid (Dayanti \& Suyatno, 2012).

Tanin merupakan senyawa polifenol yang memiki banyak gugus benzen dan hidroksil. Pada uji skrining dengan penambahan $\mathrm{FeCl}_{3}$ fenol atau tanin akan bereaksi dengan perubahan warna hijau atau biru kehitaman. Hal ini terjadi karena terbentuknya ikatan kovalen koordinasi antara ion besi (III) dengan gugus hidroksil (Suryanita, 2019). Flavonoid merupakan senyawa polar yang memiliki banyak gugus hidroksil. Pada identifikasinya digunakan serbuk $\mathrm{Mg}+\mathrm{HCl}$ pekat yang akan membentuk gelembung-gelembung $\mathrm{H}_{2}$. Penambahan $\mathrm{HCl}$ pekat, akan menghidrolisi flavonoid glikosida menjadi bentuk aglikonnya yang kemudian membentuk kompleks dengan $\mathrm{Mg}$ sehingga menghasilkan perubahan warna merah, kuning atau jingga (Suryanita, 2019).

Selain itu, flavonoid dapat diidentifikasi dengan menggunakan larutan $\mathrm{NaOH}$ yang akan memberikan reaksi dengan perubahan warna jingga kemerahan. Flavonoid memiliki gugus o-hidroksi bebas yang dengan $\mathrm{NaOH}$ akan membentuk senyawa kuinoid yang berwarna jingga kemerahan (Mulyani \& Laksana, 2011).

Saponin merupakan senyawa yang bersifat polar sehingga larut dengan air. Saponin juga memiliki gugus non polar yaitu terpenoid/steroid. Senyawa yang memiliki gugus polar dan non polar dapat 
bersifat aktif permukaan sehingga dengan pengocokan menggunakan air, akan membentuk misel dan larutan koloidal yang akan tampak seperti buih (Sangi et al., 2012). Dengan penambahan $\mathrm{HCl}$ buih akan stabil selama 5 sampai 10 menit. Pada pengujian triterpenoid atau steroid, digunakan $\mathrm{CH}_{3} \mathrm{COOH}$ a.h dan $\mathrm{H}_{2} \mathrm{SO}_{4}$. Reaksi positif triterpenoid akan menghasilkan cincin kecoklatan atau violet dan cincin hijau kebiruan jika positif mengandung steroid. Hal ini terjadi karena adanya pembentukan ikatan rangkap $\mathrm{CH}_{3} \mathrm{COOH}$ a.h dan $\mathrm{H}_{2} \mathrm{SO}_{4}$ dengan sampel (Sangi et al., 2012).

Setelah dilakukan skrining fitokimia, dilanjutkan dengan uji kualitatif pada masing-masing ekstrak metanol dan ekatrak air daun karet kebo (Ficus elastica). Pada pengujian ini, ekstrak di totolkan pada lempeng KLT kemudian dielusi. Selanjutnya diangin-anginkan dan permukaan lempeng disemprot dengan larutan DPPH 0,2 \%. Apabila terjadi perubahan warna kuning pada noda di permukaan lempeng dengan latarbelakang ungu, maka ekstrak positif memiliki aktivitas sebagai antioksidan. Adapun hasil dari uji kualitatif aktifitas antioksidan pada ekstrak metanol dan ekstrak air daun karet kebo, (Ficus elastica) dapat dilihat pada tabel berikut:

Tabel 3. Hasil uji kualitatif aktivitas antioksidan ekstrak daun karet kebo (Ficus elastica).

\begin{tabular}{ccc}
\hline Sampel & Eluen & Hasil \\
\hline ekstrak & Diklorometana : Metanol & positif \\
metanol & $(99: 1)$ & antioksidan \\
ekstrak air & Diklorometana : Metanol & positif \\
& $(95: 5)$ & antioksidan \\
\hline
\end{tabular}
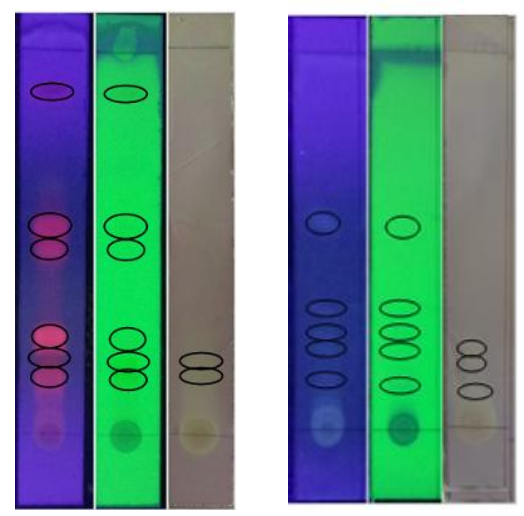

(1a) (1b) (1c) (2a) (2b) (2c)

Gambar 1. Hasil Uji Kromatografi Lapis Tipis (KLT) silika gel $\mathrm{F}_{254}$ ekstrak metanol dan ekstrak air daun karet kebo (Ficus elastica)

Keterangan :

(1a) Ekstrak metanol pada UV $366 \mathrm{~nm}$,

(1b) Ekstrak metanol pada UV $254 \mathrm{~nm}$

(1c) Ekstrak metanol setelah disemprot DPPH 0,2 \%

(2a) Ekstrak air pada UV $366 \mathrm{~nm}$,

(2b) Ekstrak air pada UV $254 \mathrm{~nm}$

(2c) Ekstrak air setelah di semprot DPPH 0,2 \%

Pada uji kuantitatif, dilakukan penentuan panjang gelombang larutan DPPH terlebih dahulu, dimana diperoleh panjang gelombang maksimal pada $516 \mathrm{~nm}$. Larutan campuran yang akan diukur di inkubasi terlebih dahulu sehingga sampel dan DPPH dapat bereaksi secara sempurna. Adanya aktivitas antioksidan pada sampel ditunjukan dengan terjadinya perubahan warna larutan dari warna ungu menjadi lebih pudar (kuning). Hal ini disebabkan karena adanya donasi atom hidrogen dari senyawa 
antioksidan ke senyawa radikal DPPH sehingga DPPH tereduksi menjadi DPPH-H. Adapun hasil dari pengukuran kuantitatif aktivitas antioksidan dapat dilihat pada tabel berikut

Tabel 4. Hasil pengukuran absorbansi, persentase inhibisi, dan nilai $\mathrm{IC}_{50}$ dari ekstrak daun karet kebo (Ficus elastica) dan pembanding Kuersetin.

\begin{tabular}{|c|c|c|c|c|}
\hline $\begin{array}{c}\text { Larutan } \\
\text { Uji }\end{array}$ & $\begin{array}{c}{[]} \\
(\mathbf{p p m})\end{array}$ & $\begin{array}{c}\text { Abs. Sampel } \\
\text { + DPPH }\end{array}$ & $\begin{array}{c}\% \\
\text { inhibisi }\end{array}$ & $\begin{array}{c}\mathrm{IC}_{50} \\
(\mu \mathrm{g} / \mathrm{mL})\end{array}$ \\
\hline & 20 & 0,722 & 15,47 & \\
\hline & 40 & 0,631 & 26,9 & \\
\hline Ekstrak & 60 & 0,532 & 38,69 & 78,39 \\
\hline \multirow[t]{4}{*}{ Metanol } & 80 & 0,443 & 49,88 & \\
\hline & 100 & 0,326 & 63,92 & \\
\hline & 20 & 0,731 & 12,97 & \\
\hline & 40 & 0,709 & 15,59 & \\
\hline \multirow[t]{5}{*}{ Ekstrak Air } & 60 & 0,691 & 17,73 & 319,11 \\
\hline & 80 & 0,675 & 20,35 & \\
\hline & 100 & 0,659 & 22,97 & \\
\hline & 2 & 0,629 & 25,11 & \\
\hline & 4 & 0,552 & 34,28 & \\
\hline \multirow[t]{3}{*}{ Kuersetin } & 6 & 0,486 & 42,14 & 7,62 \\
\hline & 8 & 0,407 & 51,54 & \\
\hline & 10 & 0,331 & 60,83 & \\
\hline
\end{tabular}

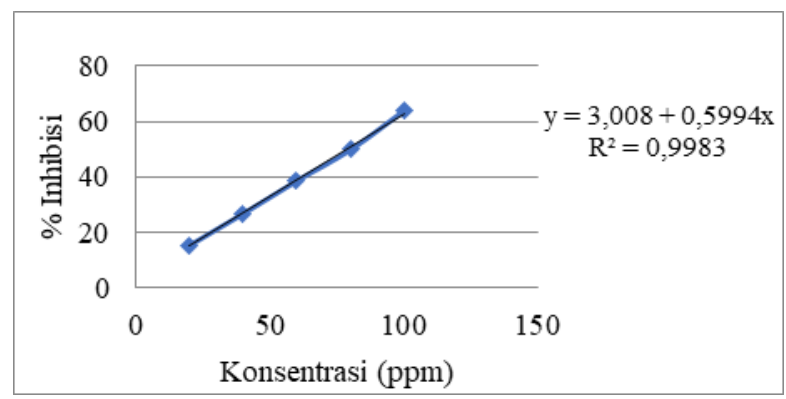

Gambar 2. Kurva ekstrak metanol

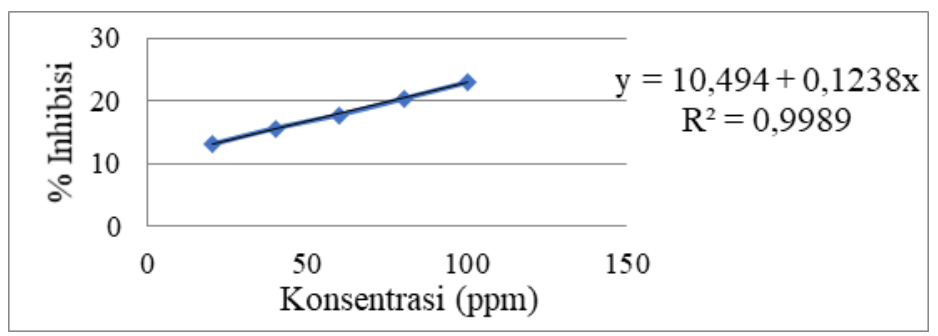

Gambar 3. Kurva ekstrak air 


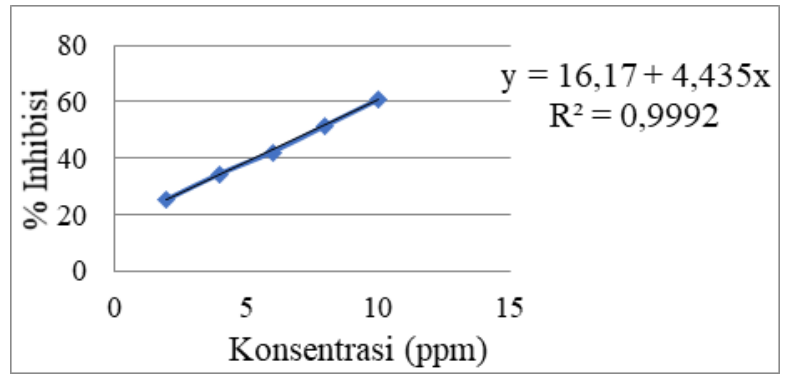

Gambar 4. Kurva pembanding kuersetin

Menurut Phongpaichit dalam Syarif et al (2016) suatu senyawa dikatakan sebagai antioksidan sangat kuat apabila memiliki nilai $\mathrm{IC}_{50}<10 \mu \mathrm{g} / \mathrm{mL}$, antioksidan kuat apabila nilai $\mathrm{IC}_{50}$ antara $10-50 \mu \mathrm{g} / \mathrm{mL}$, sedang apabila nilai $\mathrm{IC}_{50}$ berkisar antara $50-100 \mu \mathrm{g} / \mathrm{mL}$, lemah apabila nilai $\mathrm{IC}_{50}$ antara 100-250 $\mu \mathrm{g} / \mathrm{mL}$ dan tidak aktif apabila $\mathrm{IC}_{50}$ diatas $250 \mu \mathrm{g} / \mathrm{mL}$ (Syarif et al., 2016). Berdasarkan hasil penelitian ekstrak daun karet kebo (Ficus elastica), ekstrak metanol memiliki aktivitas antioksidan dengan nilai $\mathrm{IC}_{50} 78,39 \mu \mathrm{g} / \mathrm{mL}$ dengan kekuatan antioksidan sedang, sementara ekstrak air tergolong tidak aktif yang memiliki nilai $\mathrm{IC}_{50} 319,11 \mu \mathrm{g} / \mathrm{mL}$. Dimana dalam penelitian ini hasil pengukuran untuk pembanding kuersetin, memiliki nilai $\mathrm{IC}_{50}$ sebesar $7,62 \mu \mathrm{g} / \mathrm{mL}$ dan tergolong antioksidan sangat kuat.

Lemahnya aktivitas antioksidan pada ekstrak daun karet kebo (Ficus elastica) dibandingkan kuersetin, dapat disebabkan karena kandungan pada ekstrak masih dalam bentuk senyawa kompleks (tidak murni) sedangkan kuersetin merupakan senyawa yang murni. Selain itu, lemahnya ekstrak air dibandingkan ekstrak metanol, dapat disebabkan karena senyawa kimia yang tertarik dalam pelarut air masih berikatan dengan gugus glikosida dimana senyawa glikosida merupakan senyawa yang sifatnya sangat polar. Menurut Fukumoto dan Mazza dalam Ridho et al (2013), semakin banyak gugus hidroksil dalam suatu ekstrak, maka aktivitas antioksidan akan semakin meningkat. Namun aktivitas antioksidan akan menurun dengan adanya gugus glikosida.

\section{KESIMPULAN}

Berdasarkan hasil penelitian yang dilakukan dapat disimpulkan bahwa ekstrak daun karet kebo (Ficus elastica) berpotensi sebagai antioksidan, dimana ekstrak metanol daun karet kebo (Ficus elastica) tergolong antioksidan sedang dengan nilai $\mathrm{IC}_{50}$ sebesar $78,39 \mu \mathrm{g} / \mathrm{mL}$ dan ekstrak air daun karet kebo (Ficus elastica) tergolong tidak aktif sebagai antioksidan dengan $\mathrm{IC}_{50}$ sebesar $319,11 \mu \mathrm{g} / \mathrm{mL}$. Sedangkan pembanding kuersetin merupakan antioksidan sangat kuat dengan nilai $\mathrm{IC}_{50} 7,62 \mu \mathrm{g} / \mathrm{mL}$.

\section{DAFTAR PUSTAKA}

Agustina, E. (2017). Uji Aktivitas Senyawa Antioksidan dari Ekstrak Daun Tiin (Ficus Carica Linn) dengan Pelarut Air, Metanol dan Campuran Metanol-Air. Klorofil, 1(1), 38-47.

Aziz, T., Febrizky, S., Mario, A. D. (2014). Pengaruh Jenis Pelarut Terhadap Persen Yield Alkaloid Dari Daun Salam India (Murraya koenigi). Jurnal Teknik Kimia, 2(20), 1-6.

Dalimartha, S. (2008). Atlas Tumbuhan Obat Indonesia Jilid 5. Depok: Pustaka Bunda.

Dayanti, R. \& Suyatno. (2012). Aktivitas Antioksidan Ekstrak Metanol Bagian Batang Tumbuhan Paku Nephrolepis radicans (Burm.) Kuhn. Unesa Journal of Chemistry, 1(1), 86-92.

Harborne, JB. (1987). Metode Fitokimia. Penuntun Cara Modern Menganalisis Tumbuhan. Terjemahan Padmawinata K dan Soediro. I. Bandung: Penerbit ITB. 
Huselan, Y, M, Runtuwene, M, R, J, \& Wewengkang, D, S. (2015). Aktivitas antioksidan Ekstrak Etanol, Etil Asetat, dan n-Heksan dari Daun Sesewanua (Clerodendron squamatum Vahl.). Pharmacon Jurnal Imiah Farmasi, 4(3), 155-163.

Iqbal, Z. (2018). Essential Oil from The Aerial Roots of Ficus elastica and Their Antioxidant Activity. Int. J. Adv. Res, 6(1), 137-140.

Mulyani, S. \& Laksana, T. (2011). Analisis Flavonoid dan Tanin dengan Metoda MikroskopiMikrokimiawi. Majalah Obat Tradisional, 16(3), 109 - 114.

Ridho, E. A., Sari, R., \& Wahdaningsih, S. (2013). Uji Aktivitas Antioksidan Ekstrak Metanol Buah Lakum dengan Metode DPPH (2,2-difenil-1-pikrilhidrazil), (Undergraduate Thesis). Universitas Tanjungpura, Pontianak.

Saeed, A., Iqbal, Z., Gulzar, Z., Hai, Z., Akram, M., Liaqat, L., ... \& Khalil, H. I. (2017). GC-FID and Physicochemical Studies of Oil From The Leaves of Ficus elastica Linn. World Journal of Pharmaceutical Research, 6(1), 47-53.

Saifudin, A. (2014). Senyawa Alam Metabolit Sekunder Teknik Pemisahan dan Pemurnian. Yogyakarta: Deepublish.

Sangi, M., S., Momuat, L., I. \& Kumaunang, M. (2012). Uji Toksisitas dan Skrining Fitokimia Tepung Gabah Pelepah Aren (Arenga pinnata). Jurnal Ilmiah Sains, 12(2), 127-134.

Sirisha, N, Sreenivasulu, M, Sangeeta, K, \& Chetty, C, M. (2010). Antioxidant Properties of Ficus Species A Review. Int.J. Pharm Tech Res, 2(4), 2174-2182.

Suryanita. (2019). Identifikasi Senyawa Kimia dan Uji Aktivitas Antioksidan Ekstrak Etanol Kulit Jeruk Bali (Citrus maxima Merr.). Majalah Farmasi dan Farmakologi, 23(1), 16-20.

Syarif, R. A., Muhajir, M., Ahmad, A. R., Malik, A. (2016). Identifikasi Golongan Senyawa Antioksidan dengan menggunakan Metode Peredaman Radikal DPPH Ekstrak Etanol Daun Cordia myxa L. Jurnal Fitofarmaka Indonesia, 2(1), 83-89. Spektrometri. Analit: Analytical and Environmental Chemistry, 3(1), 38-46.

Wahdaningsih, S., Setyowati E. P., Wahyuono, S. (2011). Aktivitas Penangkap Radikal Bebas dari Batang Pakis (Alsophila glauca J. Sm). Majalah Obat Tradisional, 16(3), 156 - 160. 